\title{
TUMBUHAN HERBA BERPOTENSI OBAT DI KAWASAN RPH SUMBERJATI
}

\section{PLANTS OF MEDICINAL POTENTIAL GROWN IN RPH AREAS AT SUMBERJATI}

\author{
Desy Savitri Ning Tyas ${ }^{1)}$, Elfien Herrianto ${ }^{2)}$, Novy Eurika ${ }^{3)}$ \\ ${ }^{1), 2), 3)}$ Pendidikan Biologi, FKIP Universitas Muhammadiyah Jember \\ Email: dhessysavitrii06@gmail.com
}

diterima : 2 September 2019 ; dipublikasi : 30 Oktober 2019

DOI : http://dx.doi.org/10.32528/bioma.v4i2.3164

\begin{abstract}
ABSTRAK
Kawasan Resort Pemangkuan Hutan (RPH) Sumberjati, Silo, Kabupaten Jember memiliki banyak keragaman hayati, termasuk tumbuhan herba. Penelitian ini bertujuan untuk mengidentifikasi jenis tumbuhan herba berpotensi obat yang digunakan oleh masyarakat di kawasan RPH Sumberjati. Penelitian deskriptif eksploratif ini dilakukan pada bulan Apri sampai dengan Mei 2018. Pengambilan data penelitian dilakukan dengan metode jelajah dengan menelusuri jalan setapak petak 26 RPH Sumberjati bersama dengan informan kunci KRPH Sumberjati yang memiliki pengetahuan dan memanfaatkan tumbuhan herba sebagai obat. Hasil penelitian menunjukkan terdapat 29 jenis tumbuhan herba berpotensi obat yang digunakan masyarakat RPH Sumberjati. Tumbuhan herba tersebut dimanfaatkan oleh mayarakat setempat sebagai obat berbagai penyakit, seperti batuk, demam, sariawan, dan sebagainya, dengan menggunakan bagian organ tumbuhan seperti akar, daun, batang, rimpang, buah dan batang.
\end{abstract}

Kata Kunci: Tumbuhan Herba dan Potensi Obat

\begin{abstract}
The Forest Caretaker Resort area (RPH) of Sumberjati, Silo, Jember, which grows biological diversity, including various plants of medicinal potential. The present study aimed at identifying kinds of plants with medicinal potential consumed by the local inhibitants living around the Forest Caretaker Resort of Sumberjati. This descriptive explorative study was conducted on April to May 2018. Data were collected through exploring through foot steps at 26 Forest Caretaker Resort (RPH) of Sumberjati accompanied by a key infomant from RPH of Sumberjati who possessed the knowledge as well as consumed the plants with medicinal potential as daily herbsThe study found that there are 29 kinds of plants with medicinal potential consumed by the local. These plants are commonly consumed to help cure some diseases, such as cough, fever, mouth ulcer, and so on, by using some parts of the plants, namely roots, leaves, stems, rhizomes, fruits, and trunks.
\end{abstract}

Keywords: Herbaceous Plants and Drug Potentia 


\section{PENDAHULUAN}

Secara umum wilayah Kabupaten Jember terbagi dalam beberapa karakteristik wilayah berupa pegunungan, bukit, rawa, laut dan hutan tropis. Kawasan hutan di Kabupaten Jember sebagian berada dibawah pengelolaan KPH Jember yang merupakan salah satu unit manajemen di wilayah Divisi Regional Jawa Timur. KPH Jember memiliki luas wilayah 71.525,14 Ha yang meliputi kawasan hutan di wilayah Administratif Kabupaten Jember dan terbagi dalam 3 wilayah Bagian Hutan (BH), 7 wilayah Bagian Kesatuan Pemangkuan Hutan (BKPH), dan 24 wilayah Resort Pemangkuan Hutan (RPH), diantaranya adalah RPH Sumberjati (Putra, 2019).

Kawasan RPH Sumberjati termasuk di dalam wilayah Bagian Kesatuan Pemangkuan Hutan (BKPH) Sempolan yang terletak di Desa Sumberjati, Kecamatan Silo Kabupaten Jember. Desa Sumberjati memiliki luas wilayah \pm 427,1470 Ha/Km, dan berbatasan langsung dengan desa Sumber Salak, Garahan, Silo, dan Sempolan di wilayah utara, timur, selatan, dan barat. Sebagai kawasan wilayah pengelolaan hutan, RPH Sumberjati didominasi oleh tanaman-tanaman budidaya seperti pinus, kayu putih, damar, sengon dan juga mahoni. Selain itu, RPH Sumberjati juga menyimpan keanekaragaman hayati tumbuhan lain, termasuk tumbuhan herba.

Tumbuhan herba merupakan tumbuhan pendek (0,3-2 meter) tidak mempunyai kayu dan berbatang basah karena banyak mengandung air (Hutasuhut, 2018). Tumbuhan herba bersifat kosmopolit di alam karena sangat mudah menyebar dan tumbuh hampir di semua tempat atau habitat, sehingga mempunyai jumlah yang sangat besar di alam (Amna Emda, 2011 dalam Marhamah, 2016). Sebagai salah satu tumbuhan penyusun hutan, herba memiliki daya saing yang kuat dan adaptasi yang tinggi terhadap tumbuhan disekitarnya (seperti semak, perdu, bahkan pohon) sehingga mampu tumbuh di tempat yang kosong (Hutasuhut, 2018).

Profil mata pencaharian masyarakat di kawasan RPH Sumberjati utamanya adalah bertani dengan mengelola kawasan hutan ataupun kawasan sekitarnya, bertanam buah- buahan, dan memelihara ternak. Masyarakat di 
kawasan ini secara turun temurun telah mengenal dan memanfaatkan jenis-jenis tanaman herba dalam kehidupan sehari-hari, yaitu sebagai tumbuhan obat. Tumbuhan berkhasiat obat adalah jenis tumbuhan yang ada pada bagian-bagian tertentu baik akar, batang, kulit, daun maupun hasil ekskresinya dipercaya dapat menyembuhkan atau mengurangi rasa sakit (Noorhidayah \& Sidiyasa, 2006). Bagian tumbuhan seperti daun, buah, bunga, akar, rimpang, batang (kulit), dan getah (resin) dimanfaatkan sebagai oleh masyarakat tradisional sebagai obat (Yassir dan Asnah, 2018). Bagian-bagian tumbuhan tersebut dimanfaatkan secara langsung maupun melalui proses pengolahan terlebih dahulu.

Tumbuhan obat yang beranekaragam jenis, habitus dan khasiat mempunyai peluang besar serta memberi kontribusi bagi pembangunan dan pengembangan masyarakat di sekitar kawasan hutan. Berbagai keuntungan yang dihasilkan dengan berperannya tumbuhan obat di sekitar kawasan hutan adalah pendapatan, kesejahteraan, konservasi berbagai sumberdaya, pendidikan nonformal, keberlanjutan usaha dan penyerapan tenaga kerja serta keamanan sosial (Hamzari, 2007). Pengetahuan dan kearifan lokal masyarakat kawasan RPH Sumberjati dalam memanfaatkan tumbuhan sebagai obat merupakan salah satu bentuk upaya pelestarian (konservasi) serta pengembangan potensi hutan. Oleh arena itu diperlukan studi ekspolarasi guna memberikan wawasan dan informasi kepada khalayak, khususnya berkaitan dengan tumbuhan herba berpotensi obat di kawasan RPH Sumberjati Kecamatan Silo Kabupaten Jember.

\section{METODE PENELITIAN}

Penelitian ini dilaksanakan pada bulan April sampai dengan Mei 2018, denga lokasi penelitian di kawasan hutan RPH Sumberjati Desa Sumberjati Kecamatan Silo Kabupaten Jember. Tahapan pertama dalam penelitian ini adalah penentuan informan kunci yaitu masyarakat yang sering menggunakan tanaman herba sebagai obat di kawasan RPH Sumberjati. Informan kunci ini selanjutnya bertindak sebagai narasumber, dalam hal ini adalah kepala RPH dan sesepuh desa yang banyak memanfaatkan tanaman herba untuk obat di kawasan tersebut. Selanjutnya adalah tahap observasi lapangan yang dilakukan untuk mengetahui 
jenis-jenis tumbuhan herba berpotensi obat yang ada di kawasan RPH Sumberjati. Tahap ini dilakukan dengan metode jelajah, yaitu dengan cara berjalan menyusuri jalan setapak dari titik pusat sampai titik akhir kurang $\pm 3 \mathrm{~km}$ dengan luas wilayah 5 Ha dari arah kiri dan kanan dari jalur.
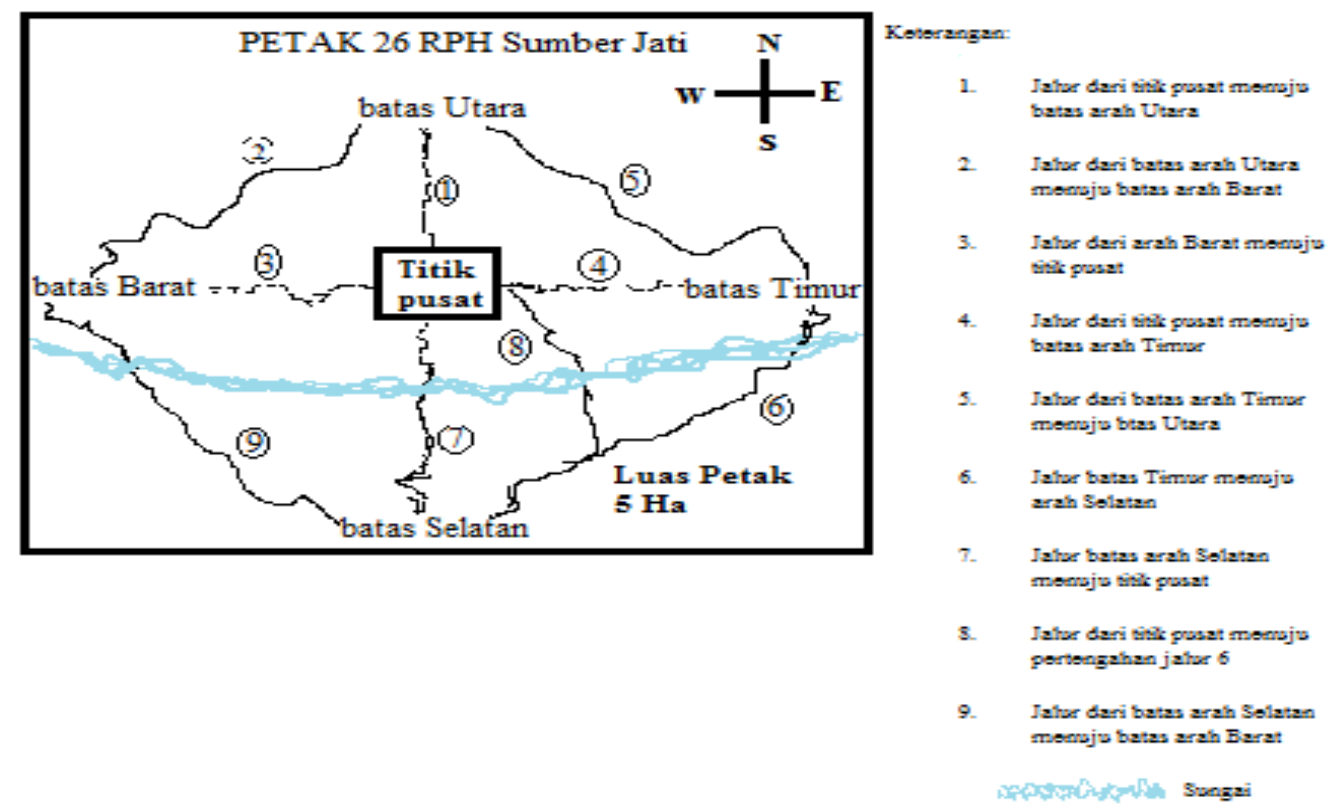

Gambar 1. Jalur Penjelajahan Pengambilan Sampel

Pada tahap tersebut, setiap jenis tumbuhan yang dimanfaatkan sebagai bahan obat tradisional dicatat nama lokal, jenis penyakit yang diobati, bagian yang digunakan, cara pengolahannya. Sedangkan identifikasi nama ilmiah yang mengacu pada Taksonomi Tumbuhan Obat-Obatan (Tjitroepomo, 2010), Tumbuhan Obat (Tampubolon (1981), tanaman Berkhasiat Obat Indosesia Jilid I (Wijayakusuma, 1996), dan Kitab Tanaman Berkhasiat Obat 226 Tumbuhan Obat Untuk Penyembuhan Penyakit dan Kebugaran Tubuh (Herbie, 2015).

\section{HASIL DAN PEMBAHASAN}

Hasil identifikasi tumbuhan herba berpotensi obat di kawasan Resort Pemangkuan Hutan (RPH) Sumberjati Desa Sumberjati Kecamatan Silo Kabupaten menunjukkan adanya 29 jenis tumbuhan herba berpotensi obat yang 
digunakan/dimanfaatkan oleh msyarakat di kawasan tersebut. Adapun jenis-jenis tumbuhan herba tersebut didajikan pada Tabel 1 berikut ini.

Tabel 1. Jenis Tumbuhan Herba Potensi Obat yang digunakan Masyarakat RPH Sumberjati

\begin{tabular}{|c|c|c|c|c|c|}
\hline No & Nama Lokal & $\begin{array}{l}\text { Nama } \\
\text { Ilmiah }\end{array}$ & $\begin{array}{c}\text { Bagian } \\
\text { Yang } \\
\text { Digunakan }\end{array}$ & Penyakit & Cara pengolahan \\
\hline 1 & Alang-alang & $\begin{array}{l}\text { Imperata } \\
\text { cylindrica }\end{array}$ & Akar & Diabetes & $\begin{array}{l}\text { Akar dicuci } \\
\text { direbus+kumis } \\
\text { kucing, disaring, } \\
\text { diminum }\end{array}$ \\
\hline 2 & Cocor bebek & $\begin{array}{l}\text { Kalanchoe } \\
\text { pinnata }\end{array}$ & Daun & Ginjal & $\begin{array}{l}\text { 3-5 lembar daun } \\
\text { cocor bebek dicuci, } \\
\text { direbus dengan } 3 \\
\text { gelas air hingga } \\
\text { menjadi } 1 \text { gelas } \\
\text { kemudian diminum. }\end{array}$ \\
\hline 3 & Bandotan & $\begin{array}{l}\text { Ageratum } \\
\text { conyzoides } \\
\text { L. }\end{array}$ & Daun & Luka & $\begin{array}{l}\text { 1-3 lembar daun } \\
\text { bandotan diremas } \\
\text { sampai halus } \\
\text { kemudian } \\
\text { ditempelkan pada } \\
\text { luka. }\end{array}$ \\
\hline 4 & Iler & $\begin{array}{l}\text { Coleus } \\
\text { scutellarioid } \\
\text { es }\end{array}$ & Daun & Ambeien & $\begin{array}{l}\text { 1-2 lembar daun } \\
\text { diremas kemudian } \\
\text { ditempelkan pada } \\
\text { dubur yang terdapat } \\
\text { ambeien. }\end{array}$ \\
\hline 5 & Meniran & $\begin{array}{l}\text { Premna } \\
\text { corymbosa }\end{array}$ & Daun & $\begin{array}{l}\text { Diabetes, } \\
\text { sakit } \\
\text { pinggang }\end{array}$ & $\begin{array}{l}\text { 10-15 lembar daun } \\
\text { dicuci direbus } \\
\text { dengan } 3 \text { gelas air } \\
\text { hingga menjadi } 1 \\
\text { gelas, kemudian } \\
\text { diminum }\end{array}$ \\
\hline 6 & Pegagan & $\begin{array}{l}\text { Centella } \\
\text { asiatica }\end{array}$ & Daun & Bisul & $\begin{array}{l}\text { 3-5 lembar daun } \\
\text { direbus dengan } 2 \\
\text { gelas air sampai } \\
\text { menghasilkan 1 } \\
\text { gelas air, disaring } \\
\text { kemudian diminum }\end{array}$ \\
\hline 7 & Suruhan & $\begin{array}{l}\text { Peperomia } \\
\text { pellucida }\end{array}$ & $\begin{array}{l}\text { Daun, } \\
\text { batang }\end{array}$ & $\begin{array}{l}\text { Penambah } \\
\text { nafsu }\end{array}$ & $\begin{array}{l}\text { Daun dan batang } \\
\text { tumbuhan suruhan }\end{array}$ \\
\hline
\end{tabular}




\begin{tabular}{|c|c|c|c|c|c|}
\hline No & Nama Lokal & $\begin{array}{l}\text { Nama } \\
\text { Ilmiah }\end{array}$ & $\begin{array}{c}\text { Bagian } \\
\text { Yang } \\
\text { Digunakan }\end{array}$ & Penyakit & Cara pengolahan \\
\hline & & & & makan & $\begin{array}{l}\text { dibersihkan terlebih } \\
\text { dahulu kemudian } \\
\text { ditiriskan sampai } \\
\text { airnya tidak ada. } \\
\text { Setelah itu } \\
\text { dicincang, } \\
\text { tambahkan nasi } \\
\text { dingin, ditempelkan } \\
\text { pada bagian perut. }\end{array}$ \\
\hline 8 & Sirih merah & $\begin{array}{l}\text { Piper } \\
\text { crocatum }\end{array}$ & Daun & $\begin{array}{l}\text { Bau } \\
\text { badan, } \\
\text { kurang } \\
\text { darah }\end{array}$ & $\begin{array}{l}\text { Daun direbus } \\
\text { dengan air } \\
\text { secukupnya } \\
\text { kemudian setelah } \\
\text { air mendidih api } \\
\text { dimatikan dan } \\
\text { biarkan sampai } \\
\text { dingin terlebih } \\
\text { dahulu kemudian } \\
\text { diminum. }\end{array}$ \\
\hline 9 & Anting-anting & $\begin{array}{l}\text { Acalypha } \\
\text { australis }\end{array}$ & Daun & $\begin{array}{l}\text { Diare dan } \\
\text { batuk }\end{array}$ & $\begin{array}{l}\text { Daun tumbuhan } \\
\text { anting-anting yang } \\
\text { sudah dikeringkan } \\
\text { dengan } 30-60 \text { gram } \\
\text { direbus kemudian } \\
\text { diminum } \\
\text { ramuannya dengan } \\
\text { air rebusan } \\
\text { secukupnya. }\end{array}$ \\
\hline 10 & Ciplukan & $\begin{array}{l}\text { Physalis } \\
\text { angulata }\end{array}$ & $\begin{array}{l}\text { Akar, daun, } \\
\text { batang }\end{array}$ & Demam & $\begin{array}{l}\text { Daun, batang,akar } \\
\text { dicuci, direbus } \\
\text { dengan } 3 \text { gelas air } \\
\text { hingga menjadi } 1 \\
\text { gelas, kemudian } \\
\text { diminum }\end{array}$ \\
\hline 11 & Serreh & $\begin{array}{l}\text { Cymbopogo } \\
n \text { nardus }\end{array}$ & $\begin{array}{l}\text { Akar, } \\
\text { batang }\end{array}$ & $\begin{array}{l}\text { Bau } \\
\text { badan, } \\
\text { pegel linu }\end{array}$ & $\begin{array}{l}\text { Batang diparut, } \\
\text { diperas, diambil } \\
\text { airnya kemudian } \\
\text { diminum. }\end{array}$ \\
\hline 12 & Pecut kuda & $\begin{array}{l}\text { Stachytarph } \\
\text { eta } \\
\text { jamaicensis }\end{array}$ & Daun & Luka luar & $\begin{array}{l}\text { Bagian daunnya di } \\
\text { tumbuk kemudian } \\
\text { dibubuhkan pada } \\
\text { area yang terdapat } \\
\text { luka luar. }\end{array}$ \\
\hline
\end{tabular}




\begin{tabular}{|c|c|c|c|c|c|}
\hline No & Nama Loka & $\begin{array}{l}\text { Nama } \\
\text { Ilmiah }\end{array}$ & $\begin{array}{c}\text { Bagian } \\
\text { Yang } \\
\text { Digunakan }\end{array}$ & Penyakit & Cara pengolahan \\
\hline 13 & $\begin{array}{l}\text { Lidah } \\
\text { buaya }\end{array}$ & Aloe vera $L$ & Daun & $\begin{array}{l}\text { Menyubur } \\
\text {-kan } \\
\text { rambut }\end{array}$ & $\begin{array}{l}\text { Bagian luarnya } \\
\text { dikupas sedikit } \\
\text { kemudian bagian } \\
\text { daging lidah buaya } \\
\text { digosokkan pada } \\
\text { kulit kepala. }\end{array}$ \\
\hline 14 & $\begin{array}{l}\text { Pandan } \\
\text { wangi }\end{array}$ & $\begin{array}{l}\text { Pandanus } \\
\text { tectorius }\end{array}$ & Daun & $\begin{array}{l}\text { Lemah } \\
\text { saraf }\end{array}$ & $\begin{array}{l}\text { Daun pandan segar } \\
\text { sebanyak } 3 \text { lembar } \\
\text { dicuci lalu dipotong } \\
\text { kecil-kecil. Rebus } \\
\text { dengan } 3 \text { gelas air } \\
\text { bersih sampai } \\
\text { tersisa } 2 \text { gelas. } \\
\text { Setelah dingin } \\
\text { disaring lalu } \\
\text { diminum pagi dan } \\
\text { sore hari, masing- } \\
\text { masing } 1 \text { gelas. }\end{array}$ \\
\hline 15 & Sambiloto & $\begin{array}{l}\text { Andrographis } \\
\text { paniculata }\end{array}$ & Daun & Diabetes & $\begin{array}{l}\text { 10-20 lembar daun } \\
\text { dicuci direbus } \\
\text { dengan } 3 \text { gelas air } \\
\text { hingga menjadi } 1 \\
\text { gelas, kemudian } \\
\text { diminum. }\end{array}$ \\
\hline 16 & $\begin{array}{l}\text { Daun } \\
\text { sendok }\end{array}$ & $\begin{array}{l}\text { Plantago } \\
\text { major L. }\end{array}$ & Daun & $\begin{array}{l}\text { Pegel linu } \\
\text { dan asam } \\
\text { urat }\end{array}$ & $\begin{array}{l}\text { Digiling atau } \\
\text { dihaluskan } \\
\text { sebanyak } 3 \text { lembar } \\
\text { daun kemudian } \\
\text { dioleskan pada } \\
\text { bagian yang } \\
\text { mengalami pegel } \\
\text { linu dan area asam } \\
\text { urat. }\end{array}$ \\
\hline 17 & $\begin{array}{l}\text { Belimbing } \\
\text { alas/ } \\
\text { calingcing }\end{array}$ & $\begin{array}{l}\text { Oxalis } \\
\text { corniculata }\end{array}$ & $\begin{array}{l}\text { Daun dan } \\
\text { buah }\end{array}$ & Sariawan & $\begin{array}{l}\text { Daunnya dapat } \\
\text { direbus kemudian } \\
\text { diminum airnya dan } \\
\text { pada bagian } \\
\text { buahnya dapat } \\
\text { langsung dimakan } \\
\text { untuk sakit } \\
\text { sariawan. }\end{array}$ \\
\hline 18 & $\begin{array}{l}\text { Lidah } \\
\text { mertua }\end{array}$ & $\begin{array}{l}\text { Sanseviera } \\
\text { trifasciata }\end{array}$ & Daun & $\begin{array}{l}\text { Sakit } \\
\text { Tenggoro }\end{array}$ & $\begin{array}{l}\text { Daun di potong- } \\
\text { potong direbus }\end{array}$ \\
\hline
\end{tabular}




\begin{tabular}{|c|c|c|c|c|c|}
\hline No & Nama Loka & $\begin{array}{l}\text { Nama } \\
\text { Ilmiah }\end{array}$ & $\begin{array}{c}\text { Bagian } \\
\text { Yang } \\
\text { Digunakan }\end{array}$ & Penyakit & Cara pengolahan \\
\hline & & & & $\begin{array}{l}\text { kan dan } \\
\text { Kekurang } \\
\text {-an } \\
\text { Vitamin }\end{array}$ & $\begin{array}{l}\text { dengan } 3 \text { gelas air } \\
\text { tersisa } 1 \text { gelas air } \\
\text { minum. }\end{array}$ \\
\hline 19 & Temulawak & $\begin{array}{l}\text { Curcuma } \\
\text { xanthorrhiza }\end{array}$ & Rimpang & $\begin{array}{l}\text { Nafsu } \\
\text { makan }\end{array}$ & $\begin{array}{l}\text { Rimpang dicuci } \\
\text { sampai bersih, } \\
\text { diparut, diperas, } \\
\text { disaring, tambahkan } \\
\text { garam (sedikit) lalu } \\
\text { diminum. }\end{array}$ \\
\hline 20 & Kencur & $\begin{array}{l}\text { Kaempferia } \\
\text { galanga } L\end{array}$ & Rimpang & Batuk & $\begin{array}{l}3-5 \mathrm{~cm} \text { rimpang } \\
\text { diparut, diperas + } \\
\text { gula merah, } \\
\text { diminum }\end{array}$ \\
\hline 21 & Jahe gajah & $\begin{array}{l}\text { Zingiber } \\
\text { officinale } \\
\text { Rosc. }\end{array}$ & Rimpang & $\begin{array}{l}\text { Perut } \\
\text { mulas }\end{array}$ & $\begin{array}{l}\text { Jahe diparut } \\
\text { sebanyak 2-3 } \\
\text { rimpang kemudian } \\
\text { diperas untuk } \\
\text { diambil airnya. } \\
\text { Diminnum 3x1 hari } \\
\text { 1sdt. Pengobatan } \\
\text { diulang selama } 3 \\
\text { hari. }\end{array}$ \\
\hline 22 & $\begin{array}{l}\text { Jahe } \\
\text { merah }\end{array}$ & $\begin{array}{l}\text { Zingiber } \\
\text { officinale var } \\
\text { rubrum } \\
\text { Theilade }\end{array}$ & Rimpang & $\begin{array}{l}\text { Gatal- } \\
\text { gatal }\end{array}$ & $\begin{array}{l}\text { Haluskan } 15 \text { gr } \\
\text { jahe, } 3 \text { siung } \\
\text { bawang merah, lalu } \\
\text { ditempelkan } \\
\text { ditempat luka. } \\
\text { Lakukan secara } \\
\text { rutin sampai } \\
\text { sembuh. }\end{array}$ \\
\hline 23 & $\begin{array}{l}\text { Lengkuas / } \\
\text { laos }\end{array}$ & $\begin{array}{l}\text { Alpinia } \\
\text { galanga }\end{array}$ & Rimpang & Panu & $\begin{array}{l}\text { Rimpang di } \\
\text { bersihkan terlebih } \\
\text { dahulu dari tanah } \\
\text { yang menempel } \\
\text { kemudian diiris } \\
\text { bagian luarnya dan } \\
\text { digosokkan pada } \\
\text { daerah yang terkena } \\
\text { panu. }\end{array}$ \\
\hline 24 & $\begin{array}{l}\text { Kunyit / } \\
\text { kunir }\end{array}$ & $\begin{array}{l}\text { Curcuma } \\
\text { dimestica }\end{array}$ & Rimpang & Diare & $\begin{array}{l}5-7 \text { cm kunyit } \\
\text { dicuci, diparut, } \\
\text { tambahlan kapur }\end{array}$ \\
\hline
\end{tabular}




\begin{tabular}{|c|c|c|c|c|c|}
\hline No & Nama Lokal & $\begin{array}{l}\text { Nama } \\
\text { Ilmiah }\end{array}$ & $\begin{array}{c}\text { Bagian } \\
\text { Yang } \\
\text { Digunakan }\end{array}$ & Penyakit & Cara pengolahan \\
\hline & & & & & $\begin{array}{l}\text { sirih (sedikit), } \\
\text { disaring, kemudian } \\
\text { diminum. }\end{array}$ \\
\hline 25 & Daun ungu & $\begin{array}{l}\text { Graptophyllum } \\
\text { pictum }\end{array}$ & Daun & Ambien & $\begin{array}{l}\text { Direbus dengan } 2 \\
\text { gelas air +daun } \\
\text { sendok hingga } \\
\text { mendidih sampai } \\
\text { segelas, disaring, } \\
\text { diminum }\end{array}$ \\
\hline 26 & Krokot & $\begin{array}{l}\text { Portulaca } \\
\text { oleracea L. }\end{array}$ & $\begin{array}{l}\text { Daun, } \\
\text { batang, } \\
\text { akar }\end{array}$ & Diabetes & $\begin{array}{l}\text { Ambil krokot yang } \\
\text { kecil-kecil, beserta } \\
\text { dengan batangnya } \\
\text { secukupnya, } \\
\text { kemudian bersihkan } \\
\text { sampai bersih dan } \\
\text { rebus dengan } 4 \\
\text { gelas air. Setelah } \\
\text { rebusan tersisa } 3 \\
\text { gelas, saring dan } \\
\text { minum air rebusan } \\
\text { nya sebanyak } 2 \text { kali } \\
\text { sehari. }\end{array}$ \\
\hline 27 & Kemangi & $\begin{array}{l}\text { Ocimum } \\
\text { basilicum }\end{array}$ & Daun & Bau badan & $\begin{array}{l}\text { Daun kemangi } \\
\text { dapat dimakan } \\
\text { langsung sebagai } \\
\text { lalap untuk makan. }\end{array}$ \\
\hline 28 & $\begin{array}{l}\text { Patikan } \\
\text { cina }\end{array}$ & $\begin{array}{l}\text { Euphorbia } \\
\text { thymifolia }\end{array}$ & Daun, akar & Wasir & $\begin{array}{l}\text { 1/2 genggam patikan } \\
\text { cina, } 1 / 2 \text { genggam } \\
\text { patikan kebo, } 1 \text { jari } \\
\text { rimpang kunyit, } 3 \\
\text { jari gula enau, } 3 \\
\text { gelas air direbus } \\
\text { menjadi } 1 \frac{1}{2} \text { gelas, } \\
\text { saring setelah } \\
\text { dingin. Diminum } \\
\text { sehari } 3 \text { kali } \\
\text { masing-masing } 1 / 2 \\
\text { gelas. }\end{array}$ \\
\hline 29 & $\begin{array}{l}\text { Bayam } \\
\text { duri }\end{array}$ & $\begin{array}{l}\text { Amaranthus } \\
\text { spinosus L. }\end{array}$ & $\begin{array}{l}\text { Daun, } \\
\text { batang }\end{array}$ & $\begin{array}{l}\text { Kurang } \\
\text { darah }\end{array}$ & $\begin{array}{l}\text { Daun direbus } \\
\text { dengan } 3 \text { gelas air } \\
\text { hingga mendidih ( } 1 \\
\text { gelas), disaring dan } \\
\text { diminum }\end{array}$ \\
\hline
\end{tabular}


Sumber: diolah dari data primer, 2018

Berdasarkan Tabel 1. diketahui terdapat 29 jenis tumbuhan herba yang digolongkan ke dalam 19 famili yang dimanfaatkan oleh masyarakat di kawasan RPH Sumberjati Desa Sumberjati sebagai obat tradisional. Berdasarkan wawancara dengan 4 orang informan yang terdiri atas: (1) Ketua RPH Sumberjati yang mengetahuai tumbuhan herba yang digunakan sebagai obat; (2) sesepuh desa; (3) masyarakat umum yang sering memanfaatkan tumbuhan obat. Dalam penjelajahan kawasan RPH Sumberjati ditemukan 29 jenis spesies tumbuhan herba yang dimanfaatkan sebagai obat. Tumbuhan herba tersebut tergolong ke dalam 19 famili yaitu: Acanthaceae, Amaranthaceae, Apiaceae, Asteraceae, Asphodelaceae, Crassulaceae, Euphorbiaceae, Lamiaceae, Liliaceae, Pandanaceae, Poaceae, Portulaceae, Phyllanthaceae, Plantaginaceae, Piperaceae, Solanaceae, Oxalidaceae, Verbanaceae, dan Zingiberaceae. Diantara 19 famili tumbuhan tersebut, famili Zingiberaceae adalah famili dengan jenis tumbuhan yang paling banyak ditemukan, yaitu sebanyak 6 jenis tumbuhan, diantaranya lengkuas, jahe merah, temulawak, jahe gajah, dan kunyit. Menurut Kurniati (2011) dalam Takoy, dkk (2013), famili Zingiberaceae merupakan tumbuhan yang banyak ditemukan di kawasan hutan tropis, dan secara umum dikenal oleh masyarakat Indonesia sebagai tumbuhan jahe-jahean yang dimanfaatkan sebagai obat tradisional.

Berdasarkan hasil penelitian yang telah dilakukan dengan wawancara 4 orang narasumber di RPH Sumberjati menunjukkan bahwa dari 29 jenis tumbuhan herba yang dimanfaatkan sebagai obat tergolong dalam 19 suku yang ditemukan, diketahui hampirs seluruh bagian (organ) tumbuhan tersebut dimanfaatkan, mulai dari akar, daun, rimpang, batang dan buah. Hal ini dapat dilihat pada gambar persentase berikut. 


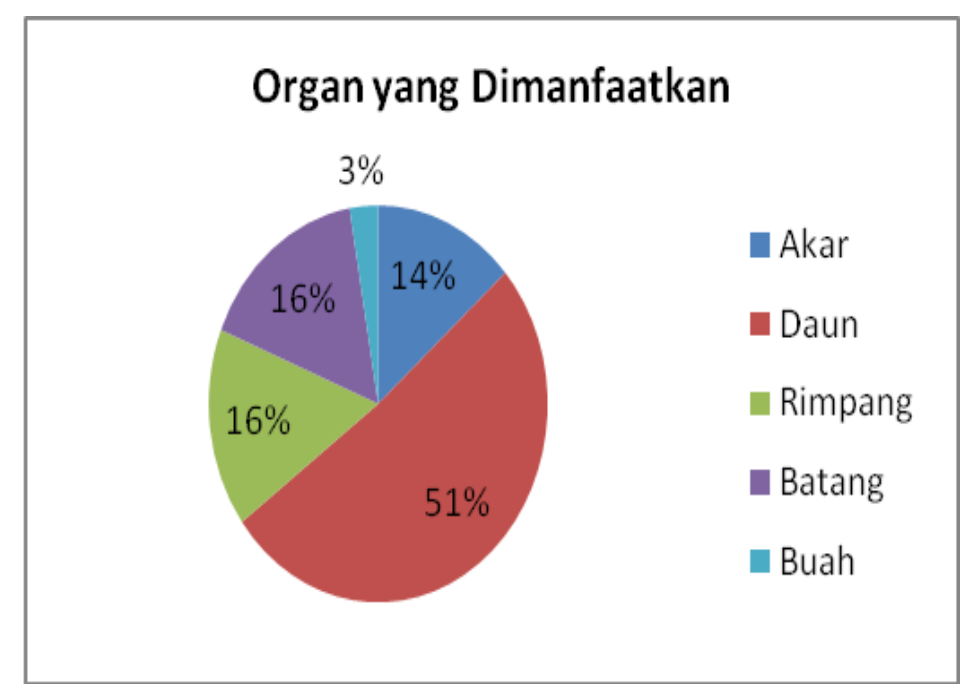

Gambar 2. Persentase Organ tumbuhan Herba yang Dimanfaatkan Masyarakat RPH Sumberjati Desa Sumberjati Kabupaten Jember.

Dari gambar diatas, diketahui persentase organ tumbuhan yang dimanfaatkan sebagai obat menunjukkan organ tumbuhan daun digunakan sebanyak $51 \%$, bagian rimpang sebanyak $16 \%$, bagian batang $16 \%$, bagian akar sebanyak $14 \%$ dan yang memiliki persentase terkecil bagian organ yang digunakan yaitu pada organ buah sebanyak 3\%. Informasi yang diperoleh dari responden menyatakan masyarakat setempat banyak memanfaatkan bagian daun tanaman herba sebagai obat berdasarkan informasi turun temurun tentang khasiat daun tanaman sebagai obat, selain juga karena bagian daun mudah diolah sebagai obat. Hal ini sesuai penjelasan Pelokang (2018), yang menyatakan bagian daun merupakan bagianyang hampir selalu melimpah di alam, sangat mudah dijumpai, pengambilan serta pengolahan daun tergolong sangat mudah dan sederhana. Berdasarakan cara pengolahannya, masyarakat kawasan RPH Sumberjati mengolah tumbuhan herba sebagai obat dengan cara yang masih sangat sederhana. Cara pengolahan paling banyak dilakukan dengan merebus bagian tumbuhan obat lalu meminum air hasil rebusan tersebut. Menurut masyarakat setempat merebus adalah cara untuk mengeluarkan kadungan obat pada tumbuhan yang diyakini berkhasiat. Menurut Yatias (2015) dalam Hadijah (2016) melalui teknik perebusan kandungan aktif yang ada di dalam daun seperti flavonoid menjadi larut dalam air sehingga mudah dicerna di dalam tubuh. Selain dengan cara Desy Savitri Ning Tyas, et al., Tumbuhan Herba. 
merebus, untuk beberapa gangguan seperti gatal-gatal dan luka, bagian tumbuhan ditumbuk/diremas dan langsung dioleskan pada bagian yang mengalami gangguan.

\section{KESIMPULAN DAN SARAN}

Jenis-jenis tumbuhan herba yang berkhasia tobat di Resort Pemangkuan Hutan (RPH) Sumberjati Desa Sumberjati Kabupaten Jember ditemukan sebanyak 29 jenis tumbuhan yang tergolong kedalam 19 famili yang pergunakan sebagai obat-obatan tradisional oleh masyarakat RPH Sumberjati.

Bagian tumbuhan yang paling banyak digunakan untuk obat oleh masyarakat RPH Sumberjati Desa Sumberjati Kabupaten Jember adalah daun yaitu sebanyak 19 jenis tumbuhan, bagian akar tumbuhan sebanyak 5 jenis tumbuhan, bagian rimpang sebanyak 6 jenis tumbuhan, bagian batang sebanyak 6 jenis tumbuhan dan bagian buah sebanyak 1 jenis tumbuhan.

\section{DAFTAR PUSTAKA}

Hadijah, S., dkk. 2016. Etnobotani Obat Tradisional oleh Masyarakat Kutai di Kecamatan Muara Bengkal Kab. Kutai Timur. Bioprospek, Jurnal Biologi FMIPA Universitas Mulawarman. Vol. 11 No. 2. September, 2018 hal. 1924.

Herbie, Tandi. 2015. Kitab Tanaman Berkhasiat Obat 226 Tumbuhan Obat Untuk Penyembuhan Penyakit Dan Kebugaran Tubuh. Yogyakarta: CV Solusi Distribusi.

Hutasutut, M.A. 2018. Keanekaragaman Tumbuhan Herba di Cagar Alam, Sibolangit. Klorofil Vol. 1 No. 2, 2018: 69-77.

Marhamah, dkk. 2016. Keanekaragaman Tumbuhan Herba di Kawasan Hutan Sekunder Desa Rinon Kecamatan Pulo Aceh Kabupaten Aceh Besar. Prosiding Seminar Nasional Biotik 2016.

Noorhidayah, \& Sidiyasa, K. 2006. Konservasi ulin (Eusideroxyl on zwageri Teijsm \& Binn) dan pemanfaatannya sebagai tumbuhan obat. Info Hutan.(Online), 3(2), 123-130, (https://media.neliti.com/.../53778-ID-riaptanaman-ulin-eusideroxylon-zwageri.pdf, diakses 03 Maret 2018). 
Pelokang, C.Y, dkk. 2018. Pemanfaatan Tumbuhan Obat oleh Etnis Sangihe di Kepulauan Sangihe Bagian Selatan, Sulawesi Utara. Jurnal Bioslogos. Vol. 8 No. 2. Agustus 2018.

Putra, D. 2019. KPH Jember. https://perhutani.co.id/tentang-kami/strukturorganisasi-perum-perhutani/divisi-regional/jatim/kph-jember/

Takoy, D.M., dkk. 2013. Tumbuhan Berkhasiat Obat Suku Dayak Seberuang di Kawasan Hutan Desa Ensabang Kecamatan Sepauk Kabupaten Sintang. Jurnal Protobiont Vo. 2 No. 3 hal. 122-128.

Tjitrosoepomo, G. 2010. Taksonomi Tumbuhan Obat-obatan. Yogyakarta: Gajah Mada University Press.

Tampubolon, O.T. 1981. Tumbuhan Obat. Jakarta: Bahatar Karya Aksara.

Yassir, M. Dan Asnah. 2018. Pemanfaatan Jenis Tumbuhan Obat Tradisional di Desa Batu Hamparan Kabupaten Aceh Tenggara. Jurnal Biotik, ISSN: 2337-9812, Vol. 6, No. 1, Ed. April 2018, Hal. 17-34.

Wijayakusuma, H. (1996). Tanaman Berkhasiat Obat Indonesia Jilid I. Jakarta:

Pustaka Kartini. 